Article

\title{
Contesting Hydropower Dams in the Eastern Himalaya: The Cultural Politics of Identity, Territory and Self-Governance Institutions in Sikkim, India
}

\author{
Rinchu Doma Dukpa ${ }^{1, *}$, Deepa Joshi ${ }^{2}$ and Rutgerd Boelens ${ }^{1,3}$ \\ 1 Department of Environment Sciences, Water Resources Management Group, Wageningen University and \\ Research, P.O. Box 47,6700 AA Wageningen, The Netherlands; rutgerd.boelens@wur.nl \\ 2 Water Governance and Feminist Political Ecology, Center for Water, Agroecology and Resilience, \\ Coventry University, Priory St, Coventry CV1 5FB, UK; deepa.joshi@coventry.ac.uk \\ 3 CEDLA Center for Latin American Research and Documentation; and Department of Geography, \\ Planning and International Development Studies, University of Amsterdam, Roetersstraat 33, \\ 1018 WB Amsterdam, The Netherlands \\ * Correspondence: rinchu.dukpa@wur.nl; Tel.: +31-317-484-190
}

Received: 9 July 2018; Accepted: 23 November 2018; Published: 26 February 2019

\begin{abstract}
In India's Eastern Himalayan State of Sikkim, the indigenous Bhutia communities, Lachungpas and Lachenpas, successfully contested all proposed hydropower projects and have managed to sustain an anti-dam opposition in their home regions, Lachung and Lachen. In this paper, we discuss this remarkable, un-researched, effective collective action against hydropower development, examining how identity and territory influence collective action through production, creation and application of vernacular knowledge systems. The role of the Dzumsa, a prevailing traditional system of self-governance among the Lachungpas and Lachenpas, has been central in their collective resistance against large dams in Lachung and Lachen. Our findings show that contrary to popular imageries, the Dzumsa is neither an egalitarian nor a democratic institution-rather, it is an exercise of an "agonistic unity". The Dzumsas operate as complex collectives, which serve to politicize identity, decision-making and place-based territoriality in their struggle against internal and external threats. Principles of a "vernacular statecraft" helped bringing the local communities together in imperfect unions to oppose modernist designs of hydropower development. However, while such vernacular institutions were able to construct a powerful local adversary to neoliberal agendas, they also pose high social, political and emotional risks to the few within the community, who chose not to align with the normative principles of the collective.
\end{abstract}

Keywords: hydropower development; politicized collective identity; territory; collective action; agonistic unity; vernacular statecraft; Dzumsa; North Sikkim

\section{Introduction}

Since 2003, over 168 large dams for hydropower development have been proposed in the Eastern Himalayan Region of India [1,2]. The push for hydropower development in the north-eastern region of India (see Figure 1) by both Central and State Governments, have made these developments highly conflict prone $[1,3,4]$. Several major contentious projects (such as the 520 MW Teesta Stage IV, 500 MW Teesta Stage VI and 300 MW Panam in Sikkim; the 2000 MW Subansari Lower HEP in Assam; the 1500 Tipaimukh Dam in Tripura; the 2880 MW Dibang Multipurpose Project and Tawang I \& II in Arunachal Pradesh, etcetera) have been stalled, delayed or are waiting for clearance across Northeast India [5-8], often characterized by prolonged struggles between dam opponents and proponents. Yet, 
the business of hydropower development continues as usual, with many official attempts to fast-track, facilitate and revive old and new hydropower projects across the north-eastern region [3-5].

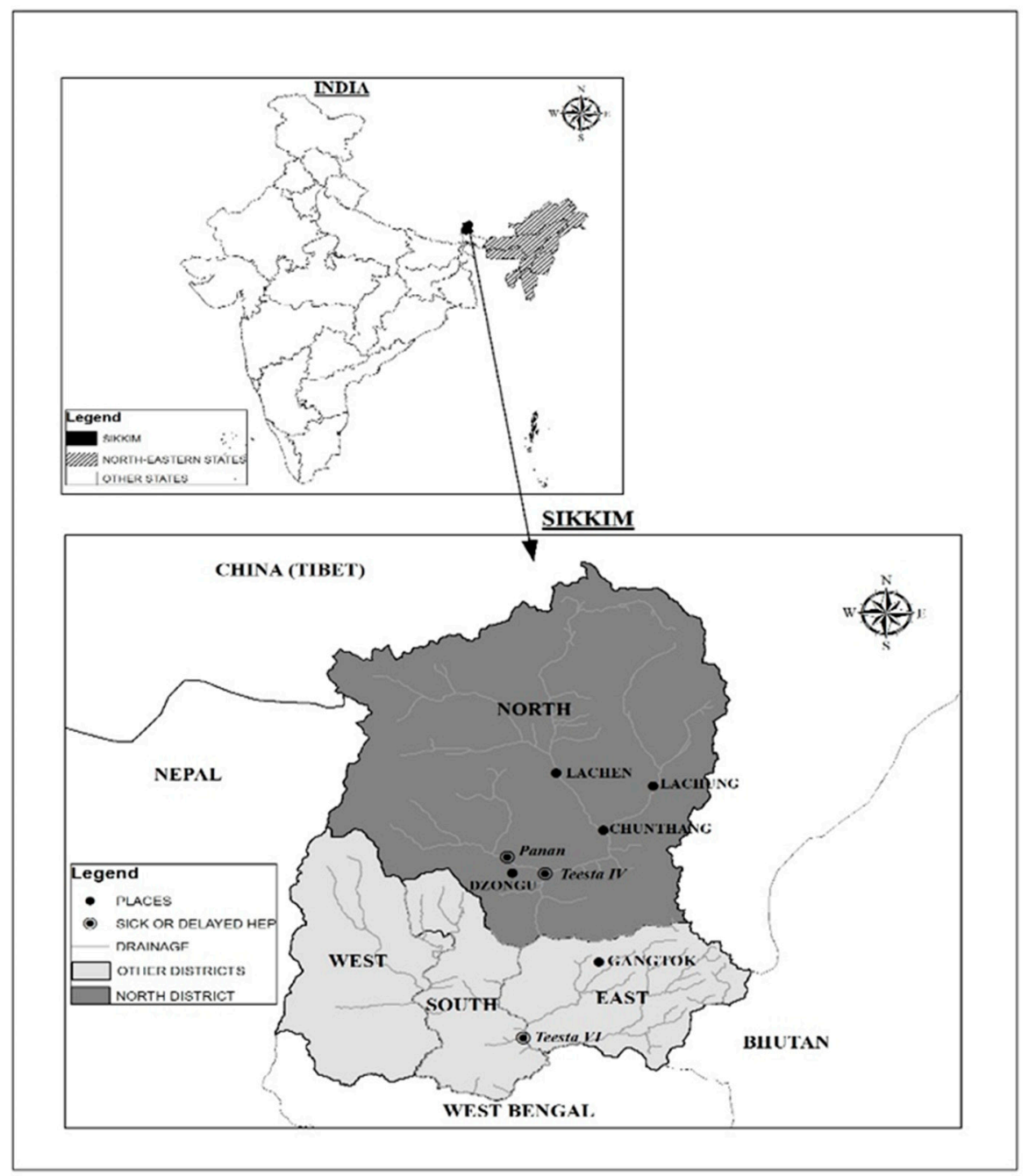

Figure 1. Delayed hydropower projects, fast tracked in Sikkim. Source: Own elaboration, adapted from GoS websites. Map not to scale.

India's most well-known anti-dam movement, the Narmada Bachao Andolan (NBA) (or Save Narmada Movement) began contesting the controversial 1450 MW Sardar Sarovar Dam on the Narmada River in 1989. Nonetheless, after three decades of resistance, which captured global attention-the Sardar Sarovar Dam was completed in 2006: a stark reminder of the powerful nexus among Government (Central, State, Local), power companies and other pro-dam advocates, who are able to pursue dam development against all odds. However, the success of the NBA movement is less about the outcome and more about the process-creating "space for India's faceless and nameless displaced" to voice and influence attention to "equitable development alongside economic growth" [9] (p. 382). It has brought to the public domain "the hitherto closed and protected discourse on mega development projects ... opening new vistas for environmental movements" [10] (p. 25).

The north-eastern region of India, where hydropower projects are being rolled out currently [7,11-13], is predominantly inhabited by diverse tribal communities. Tribal autonomy, traditional political institutions, cultures, socio-economic practices and landscapes are constitutionally protected under special provisions guaranteed by Article 371 of the Indian Constitution. Ironically, large dam development, promoted officially as instrument for "development", often happens against the wishes of many local tribal communities. This explains why unsuccessful contestations against large dams 
in the tribal north-eastern region are occasionally violent, resulting in some cases in the death of anti-dam protesters $[14,15]$. It is in this alarmingly pessimistic scenario that we draw attention to the intriguing case of how two small tribal communities, the Lachungpas of Lachung and the Lachenpas of Lachen (in North Sikkim) powerfully contested and managed within a short time frame of a few years, to cancel all the five hydropower projects proposed in their area. Regardless of the external advocacy for large dams, these two closely associated tribal communities successfully mobilized; and to this day maintain a unanimous anti-dam position. Ironically, it is the neighboring region of Dzongu, inhabited by tribal Lepchas, that literature and media consider as the epicenter of anti-dam movement in North Sikkim. Even though a few dams have been scrapped in Dzongu this is remarkable since-different from Lachung and Lachen-two mega dam initiatives have been implemented there with little resistance.

As we will discuss below, a place-based identity precedes all other identities in the case of the Lachungpas and Lachenpas. In addition, the small minority of Lachungpas (1478 in Lachung) and Lachenpas (1314 in Lachen) are amongst the few tribal groups in India, and the only ones in Sikkim who have a traditional, territorial system of self-governance known as the Dzumsa (or Dzomsa). Outsiders to these areas assume that the Lachungpas and Lachenpas are a "collective entity" united by a common Dzumsa system. It is believed that this is what enabled the community to "kick-out" hydropower companies from their respective areas. In analyzing the nature of collective action among the Lachungpas and Lachenpas and the assumed collective resistance against hydropower development in these regions, our paper unpacks complex ground realities, pointing evidence to how territory, identity and traditional governance come together to forge "agonistic unity" and "vernacular statecraft" [16].

Academic studies in various disciplines discuss how identity triggers collective action or vice versa [17-22]. Many scholars argue that within a maze of identity(ies) experienced by individuals and/or groups, there is a "specific" identity which is key to enabling collective action and/or that place (or territory) and identity $[23,24]$ are closely intertwined in protecting and strengthening cultural values, norms, shared interests and traditional territories (e.g., [25-27], see also [8,28,29]). In other words, territories or places are key markers of identity [30-32]. We have engaged here with the theoretical framework proposed by Klandermans and colleagues [17-19,33] (p. 5)—how politicized collective identity is "the engine of collective action". They outline three processes through which collective identity politicizes, triggers or mobilizes collective action, which we discuss in Section 3. Here we point out that theoretical analyses of collective action rarely pay attention to how collective actions are sustained over time and/or how consensus is maintained in any society, which is anyway divided by many fractures-class, age, gender, ethnicity, religion - to name a few. Colloredo-Mansfeld's [16] work on "vernacular statecraft" and the creation of "agonistic unity" is particularly useful in understanding how and why the Lachungpas and Lachenpas collectively and successfully protested against hydropower development in their respective areas.

Our findings reveal that territorially exclusive and ethnically cohesive collectives like the Dzumsa do not automatically or easily coalesce as a response to outsider-imposed agendas and interventions. Rather, collective action is mobilized by some individuals who politicize the notions of territorial collective identity inside and/or outside existing institutional systems, in this case, the Dzumsas. When communities are fractured into polarized groups, these vernacular institutions also become highly politicized, as they are often the means to coerce divided communities into a collective front or unity, which is nonetheless "agonistic". Here principles of "vernacular statecraft" can become highly contentious. We discuss how traditional systems and practices of shamanism (Chya) coercively bring back dissenters to "agonistic unity". As we explain, the local imposition of collective territoriality and identity notions (deploying, amongst others, fear-driven practices as the Chya) make these highland tribal communities in North Sikkim successful in maintaining their unanimous anti-dam position. Such virtues of cohesion, collective identity and action are not without contradictions. Moreover, these practices are also fundamentally at odds with liberal, modern notions of individual civil liberties. 
We have concluded that identities are not always rooted to land, territory, culture or even indigeneity, rather they are strategic, fluid, political actions that serve to defend a particular group from "outsiders/others" and(or) to protect specific claims and interests $[34,35]$. The united anti-dam stand by the Lachungpas and Lachenpas is much more than just the voicing of socio-economic and environmental concerns relating to large dams. Their resistance is really about (re)claiming territory, (re)asserting collective identity, reiterating collective action, and valuing as well as using non-official, non-centralized knowledge and modes of knowing (see [24]).

In the subsequent sections, we detail the political history of identity construction in Sikkim, to explain how the exclusive Lachungpa/Lachenpa identity came into being in the first place and sustained via the Dzumsas. A short review of key concepts in Section 3 is followed by the study area and methodology in Section 4. Our findings are described in Section 5. Section 6 gives an overview of discussions and Section 7 presents our conclusions.

\section{At the Background: Identity Dynamics in Sikkim}

To understand the anti-dam resistance in Lachung and Lachen, it is necessary to comprehend the historical, political, cultural and economic context that determines individual or collective routes to protest. Schendel's work on "Zomia" [36] or Shneiderman's on the "Himalayan Massif" [37] both describe the Himalayan region as an invisible, transnational area, "... marked by a sparse population, historical isolation ... and linguistic and religious diversity" [38] (p. 187). Before notions of nation-state crafted definite geo-political borders in the so-called Himalayan Zomia or Massif (encompassing Nepal, Bhutan, Indian States of Jammu \& Kashmir, Himachal Pradesh, Uttaranchal, Sikkim, and Arunachal Pradesh, and China including the Tibetan Autonomous Region [37]), these regions, more than being "boundary, border", were like "a zip-per" stitching together various "densely textured cultural fabrics" [39] (p. 2). The Himalayan State of Sikkim, landlocked by Bhutan in the west, Tibet in the north, Nepal in its east and India in the South (before the 1975 merger) (see Figure 1) exhibits typical "Zomian" characteristics. This explains why "society here is a constellation of multiple identities" [40] (p. 1), resulting from diverse as well as entangled "geographical, linguistic, racial, national, cultural and religious mixtures, commonalities, fluidity with neighboring" regions [37] (p. 290).

\section{1. "Sikkimese"—A Newly Created Identity?}

The oral history of Sikkim, based on myths, legends and folklore [41], goes back to the 13th century, when a blood-brotherhood-treaty was signed between the Tibetan prince Khye-Bumsa and the Lepcha Chief Thekong-thek $[40,41]$ in North Sikkim. The treaty sealed friendship between the Tibetans (who referred to themselves as the Lhopos) with the Lepchas of Sikkim (who referred to themselves as the Rongs) [40-42]. Nonetheless, modern documented history of Sikkim begins with the consecration of the Chogyal (righteous King), a Lhopo descendent in 1642 AD, leading to the establishment of the Namgyal Dynasty with a Lhopo ancestry in Sikkim (1642-1975). Sikkim's ties with Tibet thus go a long way into history and were "sustained through matrimonial, religious and trade activities including administrative support from Tibet" [41] (p. 72). Both the Lhopos and Rongs comprised of numerous clans or tribal groups, who identified themselves on the basis of their affiliation to specific territory of origin or places of habitation. In fact, the term Lhopo refers to people of South Tibet, while Rongs meant "mother's (nature's) loved one" [42] (p. 77).

It was the Nepalese who initiated the use of singular terms generalizing the diverse clans of Lhopos as "Bhotiya" meaning from "Bhot" (Tibet) and Rongs as "Lapcho" referring to people living in a heap of stone or the stone house [40] in Sikkim and across other Himalayan regions. Although Sikkim has no similar historical ties with Nepal, Nepali presence in Sikkim predates the arrival of British in Sikkim in the late 1880s as noted in the first population census of Sikkim recorded in 1891 [42]. These generic terms gained legitimacy in time. After Sikkim officially became a protectorate of the British colony of India (1889-1947) with the appointment of the first British Political Officer-John 
Claude White [41], there was a systematic in-migration of Nepali laborers into Sikkim, facilitated by the British. The terms, Bhotiya and Lapcho (or "Lapcha" in Parbatiya dialect of Nepal, where Lap meant speech and Cha meant unintelligible i.e. unintelligible speaker who could not adopt the Parbatiya language [40]) transitioned into Bhutias and Lepchas and this is how diverse groups belonging to these two generalized categories are known officially and colloquially in Sikkim. The immigrant Nepalese is also a generic category that subsumes diverse Nepali ethnic groups (such as Limbo, Khambu-rai, Yakhas, Sunuwars, Mangars, Gurungs, Tamangs, Bhujels, Thamis, Bahuns, Chettris, Kamis, Damais, Sarkis, Thakuris, Jogis, Sanyasis, Majhis and Newars in Sikkim) [42]. As we discuss below, this framing of identity by ethnicity is certainly not nuanced and does little to help explain deep-rooted and complex identities.

Following the merger of the Kingdom of Sikkim with the Republic of India in 1975, the Bhutias and Lepchas were pronounced as Scheduled Tribes under the Constitution (Sikkim) Schedule Tribes Order-derived from clause (1), Article 342 of the Indian Constitution in 1978 [41,42]. This recognition entitles these communities, privileges and protections accorded to (all) recognized indigenous tribal groups by the Indian Constitution. This GoI accreditation is also extended to all Bhutia and Lepcha communities living outside of Sikkim in the neighboring state of West Bengal, as well as Tibetan communities across the other Indian Himalayan regions of Laul-Spiti, Kumaon, Garwal referred to as the Bhotiya, Bhot or Bhoti $[43,44]$. In Sikkim, the prefix "Sikkimese" term was thus added to distinguish local inhabitants from ethnically similar outsider others (see $[13,43,44])$. This happened also because Sikkim's merger with India led to a massive in-migration of "outsiders" from all over India [41,42]. The influx of a skilled and educated outsider population evoked a conscious construction and imbibing of the Sikkimese identity, constructing what has become a sharp wedge between the Sikkimese and the non-Sikkimese. As the Sikkimese prefix came to be adopted by the later migrated Nepalis, who became the majority population in Sikkim, the minority Bhutias and Lepchas furthered their innate Sikkimese-ness, constructing more nuanced (and exclusionary) identities such as "local" and "public" implying different identities and privileges politically (see [13]). Such contentious identity-territoriality frictions define politico-ethnic fragmentations in this small Himalayan State. It is in this context, that place affiliated "Lachungpa" and "Lachenpa" terminologies are relevant, reasserted and reiterated.

\subsection{The Lachungpas and Lachenpas of North Sikkim and Their Dzumsas}

A general understanding is that Sikkimese-Bhutia groups inhabiting the valley regions of Lachung and Lachen in North Sikkim, located at an altitude of over $2500 \mathrm{~m}$ masl along the Indo-China border, are referred to as Lachungpas and Lachenpas respectively [41,45,46] - "pas" meaning "people of" in Tibetan. However, in practice, not all-Bhutia groups of Lachung and Lachen are considered as Lachungpas and Lachenpas despite decades of residence in the region. This includes Tibetans who settled in the Lachen and Lachung regions before the Chinese occupation of Tibet in the early 1950s, Tibetan refugees who settled here post the closure of Sino-Indo border after 1962, long-term resident nomadic herders-the Dokpas and some Sherpas-all with Tibetan ancestries. It makes it difficult to know how the Lachungpas and Lachenpas distinguish themselves from other Tibetan settlers and refugees, Sherpas, Dokpas of Bhutanese origin. There are many similarities between these different highland communities living in the Lachung and Lachen region: a centuries old transhumance practice i.e., migrating seasonally from one ecological zone to another (into higher Himalaya) for agricultural and pastoral activities; trade ties with Tibet [45], socio-economic and cultural commonalities that come with geographic proximity. However, an exclusive hallmark that differentiates the Lachungpas and Lachenpas from others in the region as well as across Sikkim is their traditional administrative system of local self-governance called the Dzumsa and membership in it.

Ironically, the Dzumsas have a feudal origin. The institution was set up by the Chogyal monarchy to establish authority and ensure "structural cohesiveness" for collecting land tax in the distant, far-flung regions of Lachung and Lachen [45-47]. In time, the Dzumsas also took responsibility for settling local disputes, overseeing fulfillment of cultural and religious obligations, etcetera. When 
monarchy was abolished in Sikkim in 1975, following Sikkim's merger with India, the Dzumsas of Lachung and Lachen were retained and later, conferred recognition within Sikkim (via Sikkim Panchayat Amendment Acts, 1982/1993/1995) [41]. This brought the Dzumsas at par with the Gram Panchayat - the third tier of local village self-governance system under the Panchayati Raj Institution as imposed in the rest of Sikkim [41]. Further Amendments (2001) protected the Dzumsa's customary laws, uncodified in nature, making the two Dzumsas uniquely official as well as traditional [41,42]. These unwritten customary laws bestow enormous power on the Dzumsas-making the Dzumsa rigid and flexible in executing its functioning - in contrast to Gram Panchayats that are strictly based on GoI and GoS guidelines. One of the key features of the Dzumsa is its social structure: all male heads of Lachungpa/Lachenpa households are members of their respective Dzumsa committees and thus influence the dynamics of decision making as well as the execution of the responsibilities and functions of the Dzumsa. This is hailed by many researchers as one the most traditional models of democracy $[41,45,46]$ and participation. In addition, unlike Gram Panchayats that have affiliations to political parties and where decisions are influenced by party-ideologies or agendas, the Dzumsas are deliberately politically neutral. Therefore, while individual affiliation to political parties are allowed, public displays of such affiliations are banned in Lachung and Lachen.

Elders in Lachung and Lachen explain that in earlier times, membership of the Dzumsa was open to all households resident in these regions. However, post-merger with India, the geopolitically sensitive border regions of Lachung and Lachen were the site of significant defense and infrastructural development by the GoI. This resulted in a huge influx of outsiders, including Indian Army and Border Relief Organization personnel and various categories of construction workers employed on military projects (see [13]). This made the Lachungpas and Lachenpas increasingly conscious about protecting and preserving their territory-affiliated identity and their institutions. The nomination of the first ever Minister from Lachung in the Government of Sikkim in the early 1980s and the candidate's use of the Lachungpa suffix (and not Bhutia) was a conscious re-affirmation of the place-affiliated identity. Thus, while the generalized terminology Bhutia is used by (especially younger) Lachungpas and Lachenpas in official documentation (the term brings constitutionally assigned Scheduled Tribes protections, entitlements and privileges), the older generation mostly do not use the Bhutia title. They (and the younger generation too) attach the exclusive Lachungpa or Lachenpa as a suffix after the term Bhutia to reassert their "real" identity. Today, apart from the Bhutia-Lachungpas and Bhutia-Lachenpas, other resident communities are not Dzumsa members, nor are they considered to be Lachungpas or Lachenpas in Lachung and Lachen respectively. This benefits those who were granted Dzumsa membership decades ago by virtue of their residency in the region or through marriage to Lachungpa/Lachenpa. Dzumsa membership is not a privilege for all inhabitants and expresses unequal rights. As we will discuss in Sections 5.1 and 5.2, currently, the Dzumsa is an exclusive, exclusionary institution, but before we explain this, we present a brief literature review on some selected concepts and theoretical frameworks to ground our paper.

\section{Conceptual Notions-The Plurality of Identity}

The notion of identity is complex and ambiguous, understood in myriad ways. Identity is multi-faceted [31], a social construction [48], a social process [49], a social product [50], a collective phenomenon [31], a fundamental condition of social being [51], etcetera. It is hard to pin down one's identity, being a composite of behaviors and factors, a collection of beliefs about oneself. Weinreich defines identity as a relational construct joining a person's past, present and future self-images, "... the totality of one's self-construal, in which how one construes oneself in the present expresses the continuity between how one construes oneself as one was in the past and how one construes oneself as one aspires to be in the future" [52] (p. 1). Escobar [23] (p. 203) notes that identity is an "articulation of difference(s)" that are both "dialogic and relational", which is why identity is not fixed, continuing to evolve throughout the lifespan and multiple experiences of any one individual [53]. Or as Massey [54] (p.5) says, identities "are not rooted or static, but mutable ongoing (re)productions". At the same time, 
identities are also not entirely fluid. Weinreich and Saunderson [55] note that identities constitute " ... a structural representation of the individual's existential experience, in which the relationships between self and other agents are organized in relatively stable structures over time ... with the emphasis on the socio-cultural milieu in which self relates to other agents and institutions" [52] (p. 1).

Identity exists not only at an individual, but also at relational and collective levels [56] giving rise to a plurality of individual and collective identities, which can be political, social and cultural. Whether identity is socially constructed [48], discovered, ascribed by others or dominant institutions [51], or acquired by oneself [35], according to Castells [48] (p. 7), identity derives meaning and relevance when "social actors ... internalize or acknowledge" these constructs. Thus, at any point in time, "individuals have multiple identities, which may not always work in the same direction" (i.e., may be conflicting) and collectively, any society is often fractured [17] (p. 2). This explains the complexity of cooperation, solidarities, conflicts and exclusions. While some argue that identity plays an important role in collective action, identity is not the only factor that influences collective action [57]. Other factors-such as perceived threats [58], perceived injustices [20], grievances [17,20], efficacy [20], economic interests and motives [17], norms [20], social embeddedness [19], emotions [18,20,22], appeals [17], moral and(or) inner obligations [20,59], leadership structures [22], etcetera, also influence collective action.

\subsection{Collective 'Politicized' Identity and Collective Action}

While individual identities are entirely diverse, it is shared interests and beliefs that converge to enable collective motivational interests. Here, a sense of "sameness ... manifest(s as) ... solidarity, shared disposition or consciousness, or in collective action" [60] (p. 7). Collective identity is thus better described as the identity of an individual as a group member [61] —serving "psychological functions" that relate to basic needs of the group such as belongingness, distinctiveness, respect, meanings and agency [62]. However, not all collective identities are salient at the same time; depending on contextual circumstances, collective identities can acquire or lose their relevance, position and status [61].

Klandermans [17] and many others [20-22], argue that collective identity (or identity in general) "become(s) the engine of collective action" only when politicized [18] (p. 5). Klandermans has outlined three processes for the politicization of collective identity: 1. awareness of shared grievances; 2. identification of an external adversary (against which/whom claims and grievances can be levied); and 3. obtaining the support of a legitimate, authoritative third party [17-19,33]. A politicized collective identity often instigates a strong internal, moral obligation to concerned individuals to participate in collective action [59]. As we discuss below, Klandermans analysis makes a close fit in helping unpack the construct of a Lachungpa/Lachenpa identity and the relative politicization of it against the hydropower agenda.

Melucci points out that for any grievance to be explosive, there must be a breaking point or critical threshold where conflictual reaction is triggered [22]. As he notes, "when norms or shared values are threatened by some form of imbalance or crisis, the response through which an attempt is made to re(establish) social order is centered around a common belief which, while often fictitious, mobilizes collective energies" [22] (p. 14). Further, as Boelens and Claudin [63] argue, in "adverse economic conditions, competing political influences, and the hegemonic powers that surround and penetrate $\ldots$, it is a challenge to maintain and reproduce a 'community' ... " to ensure, "the collective defense of a community's material-economic foundations ... creating and reaffirming shared norms, values, rights, and symbols" [63] (p. 1071). They state that, while collective institutions are (mostly) rational, the "rules, relations, and behaviors" that mobilize collective action are not necessarily established rationally [63] (pp. 1070-1071). Strategies driving politicized collective action are often not about rational calculations. Rather they are driven strongly by emotions, feelings and perceptions $[22,64]$. Boelens and Claudin detail how these strategies may be the "outgrowths of historical and contemporary events, of context-specific trial-and-error, of opportunities and limitations on power, and of neighboring and supralocal institutions that are incorporated" [63] (p. 1071). Critically analyzed, these processes 
debunk the often, "dogmatic myths of romanticized, rationalistic, or economist" narratives of collective action [63] (p. 1071). This explains why collective action depends deeply on trust, emotion, connect and cooperation among participants, spurred by shared understandings, experiences and identities [65].

Going beyond altruistic views, Boelens and Claudin continue to explain how collective action, not just outwardly but also internally, rests on harsh struggle to shape collective rules and orientations-inwardly, these institutions constitute "both an arena of power struggles and conflict negotiation, and a collective entity" [63] (p.1071). In the same vein, Colloredo-Mansfeld (in "Fighting like a community ..." ") [16] and Boelens and Zwarteveen (writing on water justice collectives) [66], follow Chantal Mouffe's notions of "agonistic spaces and relationships" [67]. Colloredo-Mansfeld describes how collective action rests on "agonistic unity" [16], in other words, a unity that exists despite of diverse differences (see also [68]). An agonistic unity is often mobilized via techniques or "organizational measures or strategies developed by leaders ... to administer, persuade and at times coerce residents to move towards a collective purpose" [16] (p. 7). Colloredo-Mansfeld termed this mode of arriving at consensus against the odds as vernacular statecraft. Indeed, as our research findings show, a politicized, sustained collective action against hydropower projects in Lachung and Lachen provides evidence of an agonistic unity and vernacular statecraft.

To establish and sustain effective collective action in situations of competing interests or in high-risk context where participants might face repercussion for their actions, social embeddedness of the conflict in supportive institutions is hugely strategic $[19,21,69]$. These institutions not only provide relevant resources but also make the "benefits of participation and the cost of non-participation as high as possible" [61] (p. 588). Certainly, institutions do not always politicize collective identity and mobilization [21,70]—-there are multiple ways by which "power works within communities" [71] (p. 258). Nonetheless, as we discuss below, the Dzumsas provided resources such as information and funding, and forced the community by making the benefits of participation and, especially, the costs of non-participation utterly high.

As observed by Boelens and Claudin [63] (p. 1071), maintaining and reproducing "community", its material-economic foundations and norms, values, rights and symbols, is closely interlinked with notions of territory and territoriality, which we briefly describe below.

\subsection{Territory and Territoriality}

In the research regions, both identity (as Lachungpas and Lachenpas) and its social embeddedness in the traditional institution (Dzumsas) had a strategic connect to place/territory. This weave between identity, institution and place finds resonance in the views that territories are not just formal nation state, province or other legal-administratively demarcated regions [72]. Rather, territories are geographically demarcated and cultural-politically bound spaces, constructed around and by socio-spatial authority. In a broad sense, territories link social, physical and symbolic entities: they entwine ecological systems, legal-administrative arrangements, technical-physical infrastructures, political discourses, and socio-economic livelihoods. Or as Swyngedouw and Boelens [73] (p. 117) say, "territory is the socio-materially constituted and geographically delineated organization and expression of and for the exercise of political power".

Similarly, Antonsich [74] (p. 425) argues that territory is "the socio-spatial context where the living together is produced, organized and negotiated". Territories are dynamic, historically shaped, contested and permanently negotiated. As Hommes, Boelens and Maat state: "They evolve out of social encounters and are the effect of social relations' material inscriptions that define what spaces look like and how, in turn, connected social relations are organized ... The making of territory is an interactive and continuous process that emerges from imaginaries about what a territory in its judicial, political, economic, social, cultural, affective and physical aspects, should look like" [75] (p. 3), (see also [76-78]). Importantly, therefore, this broad concept of territory includes blatant and subtle everyday struggles, disputes about discourses, and battles around the use and recognition of divergent knowledge systems. Consequently, battles over local territorial constructs and territorial governance forms deeply constitute 
and interact with identity and knowledge formation and re-creation. Territory thus has profoundly divergent meanings [26]. Territories come with "limits" and "otherness" and these demarcations are often determined by identity [79]. Territories thus are markers of identity (and vice-versa) and more often than not, enablers or disablers of processes of social exclusion perpetuating "lack or denial or resources, rights, good and services, and the ability to participate in normal relationships and activities" to some over others [80] (p. 25). Territories are therefore not static, rather, they are continually contested and actively negotiated [51].

Agnew and Oslender refer to territory as the popular acceptance of classification of space (e.g., ours versus yours), as a way of communication regarding a sense of place, and as a concept to express enforcing control over space (such as by barrier construction, interception, surveillance, policing and judicial review) [81]. As such, territoriality is usually put into practice in a number of different but complementary ways. Often, protecting physical demarcations of territory through "territoriality" serves to protect, preserve and strengthen identity and associated cultural values [26] by "affect(ing), influence(ing) or control(ing) people, phenomena, and relationships, by delimiting and asserting control over a geographic area" [82] (p. 19). In sum, identity, territory and territoriality are deeply entangled and often inseparable [31].

\section{Study Area and Methodology}

\subsection{The Study Area: Cancelled Hydropower Projects in Lachung and Lachen}

Lachung (altitude 2600 masl) means "small-mountain" and Lachen (altitude 2700 masl) "big-mountain" in Tibetan [45]. The two regions are approximately $60 \mathrm{~km}$ apart from each other and located in the North District of Sikkim. Based on the information displayed on official display boards in the local health offices in the two areas, Lachung has a population of 1478 Lachungpas (in 420 households) and 370 non-Lachungpas (in 72 households) while Lachen has 1314 Lachenpas (in 216 households) and 126 non-Lachenpas. (The total number of non-Lachenpa households in Lachen was not mentioned on the community notice board). Lachung and Lachen are administratively categorized by the GoI and GoS as "restricted" areas and remain under heavy military surveillance because both these valleys regions have mountain passes that connect Sikkim with Tibet, [45]. Travel permits including No-Objection Certificates for research activities are required to enter these areas. However, lately tourism has emerged as a booming local industry in both Lachung and Lachen.

In Lachen, two large hydropower projects, the 320 MW Teesta Stage I and the 330 MW Teesta Stage II, part of the "cascade" dams (i.e., the series of six hydropower dams-Teesta Stage I, II, III, IV, $\mathrm{V}$ and VI that were conceived as early as the 1970s) were cancelled after public protest (see Figure 2). Additionally, the 210 MW Lachen HEP and the 75 MW Talem Chu planned by multiple Independent Power Producers (IPPs) after the 2003 Hydel-Initiative Announcement by GoI were also cancelled. In Lachung, a 99 MW Lachung HEP, originally planned two dams in different sites was cancelled following local contestations. It is important to note that these valley regions are fully electrified by micro-hydel projects (3 MW Lachung Small HEP and the 3 MW Chatten HEP in Lachen) developed in the late 1980s. Another 3 MW Rabom HEP implemented in Lachen was damaged and declared non-functioning by the 2011 earthquake. Nonetheless, energy is a vital need in these high-altitude cold regions that faces frequent power cuts. It is therefore surprising that the large-scale hydropower development planned here with the promise of free electricity and other developmental gains, was fiercely opposed. 


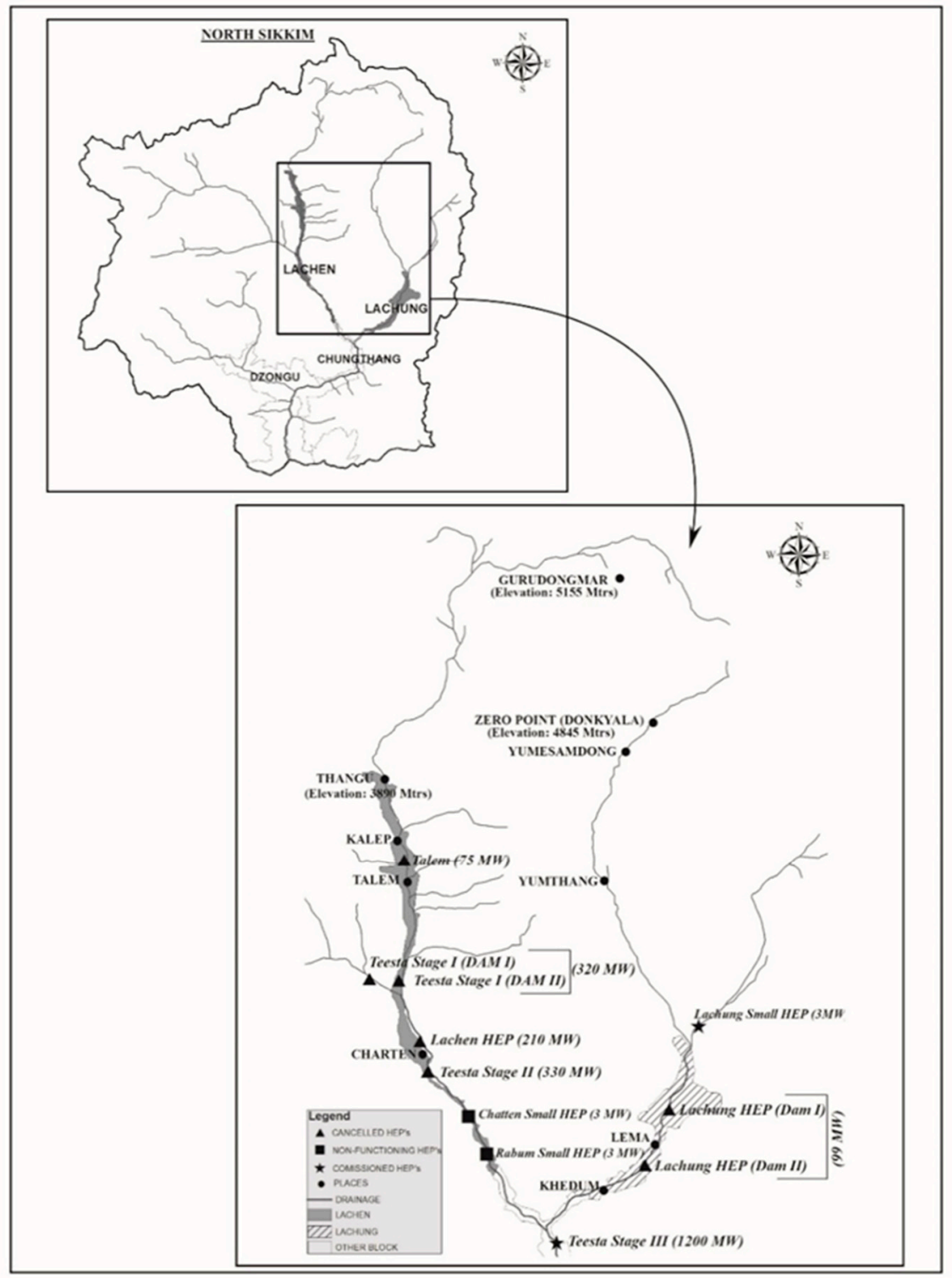

Figure 2. Hydropower Dams in Lachung and Lachen. Source: Own elaboration, adapted from GoS websites. Map not to scale.

\subsection{Methodology}

This paper draws from ethnographic research (see [83-86]) with diverse data collection methods, such as observations, semi-structured-interviews, focus group and individual discussions etcetera. The first author-researcher had been in the study area since mid-2015, first in the neighboring region of Chungthang (mid 2015-early 2016). The fieldwork in Lachung and Lachen was a continuation of the research in North Sikkim. This set the ground for meeting the Lachungpas and Lachenpas through mutual contacts (from Chungthang). Fieldwork for the current paper was conducted from late September 2016 up to February 2017 in Lachung, and resumed from end May 2017 to early October 2017 in Lachen. In the months spent in each area, familiarization with the place and its people was done through living in Lachung and Lachen and by "deep hanging out" $[84,85]$. The first author-researcher, being a woman and a non-local in the study area, conducting research, speaking to large numbers of male strangers, initially aroused suspicion and distrust in the study area. However, being a Bhutia herself, having family in Sikkim, with stays for long periods of time with local host families-gave the researcher some degree of familial connection and allowed her to be seen as an afnai-manchey 
(one of us). Attending socio-cultural and religious festivals, taking transects walks alone or with host family members and newly made friends, visiting touristic places enabled to be in the public gaze long enough to be considered a "regular". After some degree of trust and familiarity was gained, data collection was initiated with different groups of the local families residing in Lachung and Lachen: farmers, private business entrepreneurs, government employees, the unemployed, etc. Meetings with Lachungpa and Lachenpa residents, and with Tibetan, Dokpa, Sherpa, Lepcha and Nepali families, took place on an everyday basis, to strengthen confidence. The male head of Lachungpa and Lachenpa households were also members of their respective Dzumsas, who regularly attend Dzumsa meetings. In all 47 individuals were interviewed personally over a period of time (repeated meetings) and multiple discussions were conducted with a much larger number of others. Given the blanket opinion of "no dams in Lachung and Lachen", initial interactions here did not begin with questions about dams and dam resistance. Nonetheless, the purpose and nature of the research was made known to those who opposed dams blatantly as well as latently. Two power company officials were interviewed-not from the power company that the Lachungpas and Lachenpas threw out (see Section 5) but agents working at other operating hydropower projects nearby, in Chungthang and Mangan.

The next sections present our findings. We begin with a brief description of the structure and characteristics of Dzumsa and relate these with our core findings, following which, we discuss how the announcement to develop hydropower projects in the two areas triggered an agonistic unity and how the Dzumsa enabled the reordering of the collective by ensuring high risks of exclusions to those who challenged the vernacular alliance.

\section{Hydropower Development and the Politicization of Identity, Territory and Dzumsa}

\subsection{Dzumsa: Structure and Decision-Making}

Colloquially, the term, Dzumsa has three literal meanings, "a gathering place"; "an institution in charge of administrating and organizing activities within a given territory" and "the general council of villagers composed of household heads" [47] (p.95). Lachungpas and Lachenpas have their own (separate) Dzumsas, and this institution is only accessible to male head of households among the Lachungpas and Lachenpas. Unlike Gram Panchayats, administratively both Dzumsas are composed of (and chaired by) Pipons, who are normally the village-headmen. An inner core Dzumsa committee includes Gyapons (elderly males to assist Pipons), Gyembos (male members who function as messengers), Chuitimpas (male monks to assist Pipons), Tsipos/Chipons (male accountants) and Machays (male cooks). All other male heads of Lachungpas and Lachenpas households are Dzumsa members. Lachungpa and Lachenpa women are only occasionally allowed to attend Dzumsa meetings - in exceptional situations, when the male-head of household is absent or unable to attend (with a valid reason). Also, "others" residing in Lachung and Lachen are not a part of the Dzumsa, even though they are governed by Dzumsa norms and conditionalities. They do not participate in the collective decision-making.

In earlier times, Pipons were selected by the Chogyals and this post continued as a hereditary appointment in the Pipon's family. Post-monarchy, individuals who were identified as reliable were nominated by the Dzumsa members and often succession continued to follow along hereditary lines [45-47]. After monarchy was abolished post 1975, both Dzumsas began incorporating various other methods for the nomination-elections, a lottery system or simply hand raising. In Lachung, the Pipons are always elected or selected from two places-Lema and Khedum, and the Pipons from these two places officiate as Pipon 1 and II on a rotational basis. In Lachen individual Lachenpas securing the highest and second highest votes becomes Pipon-I and Pipon-II, respectively. Regardless, the two Pipons (I and II) are bestowed with equal power and functions and are responsible to dispense administrative functions and lead socio-cultural activities. Currently, in Lachung, Pipons are elected for a fixed two-year term and are appointed not by election but through a public lottery system. Pipons 
in Lachen continue to be elected through voting and are elected only for a year but unlike in Lachung, outgoing Pipons can be re-elected and continue for as many years should they garner votes.

Although extremely rare, Pipons can be ousted from their posts by the Dzumsa members any time if they failed to carry out their duties vis-a-vis the wellbeing of the community and the place. The plans to develop hydropower projects led to (such) an unprecedented removal of the Pipon(s) in Lachung, while in Lachen too, the Pipons were threatened with possible removal from the post. This power of the Dzumsa members to elect or nominate and dispose their representatives at any time and for any issue makes the Dzumsa different from Gram Panchayats, where village representatives must be elected and have a fixed five-year term. Additionally, the two Dzumsas are by choice non-political and do not allow individual party affiliation of the Dzumsa members to influence the functions and powers (as is prevalent in the Panchayat institutions in Sikkim). In fact the public displays of political party affiliation by means of flags and political canvasing were banned in both Lachung and Lachen as such acts were perceived as threats to the collective public unity and peace in the region.

Dzumsa meetings in Lachen and Lachung are called by the Pipons through Gyapons and decision-making is through unanimous consensus. However, the Pipons also have the exclusive power to take unilateral decisions on both urgent critical as well as mundane issues, which speak to the wellbeing of the place and the people. When Pipons fail or hesitate in making critical decisions, the Chuitimpas or Gyembos are consulted to assist arriving at a decision. Once decisions are made, they are relayed to the Dzumsa members, who often go by what their representatives have agreed. It is interesting to note that Dzumsa members can deliberate on and contest the decisions taken by the Dzumsa representatives. However, in turn, if the Pipon considers these arbitrations to be invalid or unreasonable, the persons making these deliberations can be fined. If the Dzumsa representatives cannot make a decision, then all Dzumsa members collectively deliberate until a majority agrees on the decision.

The Dzumsa plays a critical role in these communities-making decisions on a wide array of everyday issues that can be socio-economic, environmental, cultural, religious, law and order, etcetera. All decisions which the community must abide by. This is why, although administratively Dzumsas and its equivalent Gram Panchayats dispense the same functions, the customary and traditional laws of the Dzumsa recognized by the GoS expands the power and function of the Dzumsa beyond that of the Gram Panchayats within their territory. It allows them added power and legitimacy to impose coercive actions on the Lachungpas and Lachenpas but also on the non-Dzumsa members (i.e., the Tibetan, Sherpa, Dokpa or Nepali) like fines, impose new rules and regulations, social exclusions, boycotts, including settling of grave disputes.

Thus, while the Dzumsa is eulogized as egalitarian and democratic by many researchers, it is rather hierarchical, masculine and exclusionary in its structure and operation $[46,47]$ (p. 35). The Dzumsa was not always so closed as it is today. An elderly Lachenpa recalled, "I had heard that in the old times, Dzumsa had very few members. Of-course then our population was also very low, yet, still Dzumsa meetings were not compulsory and any one (outsiders) could join it. The members registration was so low that one had to seek people to join Dzumsa and constantly request people to undertake collective work". Sikkim's merger with India in 1975 and the subsequent marking of territory (land settlement surveys in 1978/1979 under GoI) as well as the nature and extent of translocal developments have contributed to the reassertion of a territorial collective identity among the Lachungpas and Lachenpas.

In the section below, we look at how hydropower development threatened the agonistic union of this traditional self-governing body and how the Dzumsa members resorted to 'vernacular statecraft' to restore their collective identity and institution.

\subsection{Hydropower Intervention and Politicization of Collective Identity}

Ways of living and governance in Lachung and Lachen conform to an uncodified customary and traditional system, which is deeply exclusionary. The State push for hydropower development took place in a context that has historically been politically suspicious and antagonistic. In the words of a 
male Lachenpa respondent: "If the 'company' (hydropower project) comes, they will bring with them thousands of outsiders, whose presence will dilute our existence. Our land, culture, tradition, old practices and identity are at stake. We will be outnumbered. We will be forced to relax our existing Dzumsa rules and laws to pave easy way for such developments. This way, our age-old laws, rules and regulations will slowly lose their relevance".

It was reported that the GoI announcement of the 50,000 MW Indian Hydroelectric Initiative in the North District of Sikkim in 2003 [87] led to an urgent Yul-Dru-Sum meeting in Chungthang between the Lepchas of Dzongu, the Lepchas and Bhutias living in Chungthang and the Bhutias living in Lachen and Lachung. (In Tibetan "Yul-Dru-Sum" translates to Yul meaning three, Dru meaning together and Sum meaning places i.e., the people of three places-Lachung and Lachen as one entity, Dzongu and Chungthang). This meeting was also attended by Lepchas from nearby project-affected-areas outside the administrative boundaries of North Sikkim. A momentous unanimous decision was made amongst the two indigenous groups (Lepchas and Bhutias) to not allow any power-companies in the region. A 45-year-old Lachen resident who attended the meeting recalled: "There were around 50 to 60 people that day. We discussed in detail the pros and cons of hydropower development and concluded that if such companies entered, we would be left with just the Sikkim-Subject land documents but with no land. We would have sickles in our hands but no land to farm. We agreed to all say 'no' to the company". However, just a year later in 2004, the Yul-Dru-Sum pact was violated in Chungthang, where $80 \%$ of the Lepchas welcomed the 1200 MW Teesta Stage III HEP development (see [13]). Another Lachenpa respondent who had attended the meeting felt that this happened, because, "Unfortunately we did not translate the decision to a written agreement. The Lepchas played a nice game. First, they said no, and then they negotiated for a higher amount of compensation money before saying yes".

Since 2004, the GoS had started to issue Letters-of-Intent (LoI) to power-companies, mostly Independent Power Producers (IPPs), which gave these organizations the right to access protected and reserved areas to initiate detailed surveys and investigations. The LoI also gives power-companies both the right and responsibility for contacting local communities and obtaining local consensus for planned development interventions. Private corporations are particularly skilled in making promises of development and economic gains; this is precisely what had happened in the case of the Teesta Stage III project planned in Chungthang (see [13]). As it turns out, like the Lepchas, some Lachungpas too (even if briefly) had faltered on the Yul-Dru-Sum agreement, although the Lachenpas had honored the decision.

Despite the promise to say no to hydropower development and the skepticism among Lachungpas and Lachenpas regarding such developments, an independent private power company was able to rupture the collective decision in Lachung. Talks for a 99 MW HEP hydropower project by Polyplex India Private Limited—an independent power company—went ahead here in 2005/2006 with the support of a few powerful Lachungpas, who held important government positions and lived in the capital Gangtok, as well as by a (then) Pipon of Kedum in Lachung, who gave his consent to a private company to undertake surveys along the riverbanks. According to the Pipon, he was gifted cash to distribute amongst the people of Lachung for allowing Polyplex company to begin the survey for two dams in Lachung: "I asked my people to accept the money as a gift from God and enjoy it". All Dzumsa members in Lachung had indeed accepted the money initially. "The Pipon was a well-respected man and powerful as well, his brother has been in politics for a long time. We believed him when he said that the survey would be undertaken along the rivers and that land would not be touched. Believing in him, each Lachungpa household head accepted twenty thousand Indian Rupee (equivalent to less than 300 Euro) that he distributed on behalf of the company. But when we saw that they were also assessing our land and mountains, we intervened. People might accuse us of selling out, but trust me, we didn't".

At around this time, young educated Lachungpa youth started to raise concerns about the potential impacts of such development. Initially, these concerns were not considered by the Dzumsa 
representatives. In fact, the Pipon of Lachung (who had distributed the money) refused to grant the youth an "emergency" meeting with Dzumsa members. According to a youth activist, "We were denied Dzumsa meeting by the Dzumsa representatives. Despite the restrictions placed on us, for the first time in our life, we disobeyed the norm and formal processes associated with the Dzumsa. We announced an emergency meeting publicly on a loudspeaker. Thankfully, people turned up the next day and we could place our concerns in front of everyone".

This emergency meeting led to a direct confrontation between these youth with the (then) Pipon from Khedum. The Pipon and a few of his aides were accused for a lack of transparency and money embezzlement. While such intervening in the Dzumsa's authority was unprecedented, it nonetheless, eventually led to the majority of the Dzumsa members supporting this accusation as the youth were equipped with critical questions and proofs, which led to the ousting of the Pipon from his post, and later on from Dzumsa itself. This process was supported by the other Pipon from Lema but contested by some Lachungpas who still supported the ousted Pipon-bringing much conflict within the community. The Dzumsa members were split between the Pipon of Khedum who had favored dams and the Pipon of Lema who has supported the youth—creating animosity and distrust between the once amicable inhabitants of Lachung. A Lachungpa laments, "We were so polarized initially that when one youngster from Lema attended a public meeting in Khedum in disguise to listen to their discussions about hydropower dams, he was unfortunately caught and brutally beaten."

According to the ousted Pipon, a 45-year-old Lachungpa: "I was the Pipon of Khedum in 2010. The company informed me during my tenure that the sites selected for the project earlier were not correct, and they only wanted to see where the first survey had been done. Just on that premise, Dzumsa members kicked me out of the Pipon post." However, a Lachungpa Dzumsa member added that: "It was forbidden to even talk about the company in Lachung, forget about entertaining their calls or talks. The second ousted Pipon did not consult us, or bring the matter to us, so we kicked him out of the post. We will remove anyone from that position who does gaddhar [betrays] to us and our place." Hydropower issues trigered the Lachungpas to mobilize and assert their voice and might; and not always in the most positive ways. Some days after the Pipon had been expelled, a violent confrontation took place when the Polyplex Company began drilling tests in the nearby mountains. "They started to dig through our mountains and take our stones. That was it! It was evening, these people were camping in tents. We burnt their tents, shouted at them and kicked them. Some of them were cooking food. We kicked their pots of rice, hurled them into trucks, drove them outside of Lachung and threatened them to never come back. Eventually, we regretted that we had attacked poor laborers, who were just doing what they were tasked by the company". These violent protests continued in Lachung, where company vehicles were damaged and local residents (Lachungpas and non-Lachungpas) working for the company were threatened to quit working or be ousted from Lachung.

The first expelled Pipon of Kedum, however was unshaken by the stand against him and became a prominent dam supporter. Being powerful and politically well-connected, his expulsion from Dzumsa was re-negotiated and he was allowed to retain his Dzumsa membership, from where he lobbied harder for the dam projects. In his words, "I managed to transport people in 45 to 47 vehicles from Lachung to the District Collector's Office at Mangan, where I confronted the anti-hydropower people from Lachung. I answered every charge levied against me, and finally I asked the District Magistrate to 'welcome' the company back to Lachung and continue their work. That the company didn't go back, is not my fault. It simply shows that it was a weak company".

Although it was in Lachen that the CWC had started the planning for hydropower development, Lachen was the last of the three regions where dams were announced. The time lag between the first dam planning processes in Chungthang and then in Lachung allowed the Lachenpas to observe and understand how coercion in dam development takes place. By the time the power companies went to Lachen to get an agreement on two hydropower projects, the Lachenpas felt they understood the politics of dam development. 
The Lachenpas adhered to an absolute "no" right from the very beginning. Unlike in Lachung, where one Pipon and his supporters became local mediators within the Dzumsa for the private company, in Lachen, a powerful collective of Government officials, the power-company, National Hydroelectic Power Corporation (NHPC) as well as Ministers went directly to meet the Dzumsa members of Lachen and seek their approval for multiple hydropower projects in 2005. At this meeting, the Dzumsa members of Lachen remained firm —-their verdict was a unanimous "no": "We knew this powerful group of individuals were coming to talk about hydropower development. The Minister accompanying them was a Lachungpa, so we told him directly, take your proposal to your own place, Lachung. The Dzumsa had called a meeting a day before, where we had deliberated and collectively decided to say no. When the group came for the Dzumsa meeting and sat in the Dzumsa hall, we closed all the doors and latched it. This might have intimidated them. The moment our Minister started talking about the company, people shouted ... We were hostile and managed to scare them off". This development also resulted in significant tensions between the Lachungpas and Lachenpas. The Lachenpas managed to dethrone the Lachungpa Minister. "We were so angry at our Minister. He being a Lachungpa, brought the group here. A devastation masked as development for us here! We considered him our own and had supported him for a long time. However, after that meeting, we told the Chief Minister of Sikkim that all of us at Lachen would no longer support his party and would join the opposition party if the Lachungpa Minister continued in the cabinet. Soon thereafter another person was given the ticket to represent North Sikkim". The power companies (NHPC and a few IPPs such as Hima Giri) tried approaching the Dzumsa many times and eventually managed, like in Lachung, to convince one of the Pipons there to speak on their behalf. However, this did not yield any positive outcome.

A deep distrust, even paranoia, for power companies took root among the Lachungpas and Lachenpas. In fact, company representatives were forcibly asked to leave Lachen when he had visited Lachen as merely a tourist. Another Lachungpa recalled: "Our people have become fearful about the company. I was once urgently called by our elders who told me that some company people had sneaked into Lachung with their instruments and were taking pictures of our rivers. I rushed, to find the intruders surrounded by our village people. As it turned out, these were mere tourists, using a tripod to take pictures near the river". Below we describe the various strategies adopted by the Lachungpas and Lachenpas to counter not just the power companies but the distrust, disunity and animosity that had crept within and in-between their communities-where the power of the Dzumas becomes imperious and unlike Gram Panchayats, becomes "binding" in determining proand anti-dam positions among the Lachungpas and Lachenpas.

\subsection{Agonistic Unity: Dzumsa, Anti-Hydropower Resistance and Vernacular Statecraft}

In Lachung, following the brief tryst with the Polyplex company and the internal fractures, an oath was taken by many Dzumsa members at Thomchi Gumpa in 2010, their main monastery, to never allow a hydropower company to enter Lachung. At this oath ceremony, fears of social exclusion and boycott from Dzumsa were announced for any remaining pro-dam supporters. This was followed by a series of new conditions set for Dzumsa members of Lachung: firstly, only those individuals who contested all hydropower projects would be eligible to become Pipons; secondly, all Lachungpas were restricted from talking about or to "company persons", at least within the borders of Lachung. In fact many Lachungpas even collected and submitted their land documents to the anti-dam faction of Dzumsa members to not fall prey into selling their lands to power companies or the pro-dam faction. In Lachen, despite the unanimous decision of no-dams, Dzumsa members came up with similar new rules for its larger residents: no one was allowed to lobby for any company; no hotel owners were allowed to host hydropower "company" people, even if they came in as tourists; no shops were allowed to sell anything, including water to the company people, no one was allowed to talk or negotiate with company. If anyone was found doing these, they would be boycotted from the society and sanctioned out of the Dzumsa. 
However, both in Lachung and Lachen-these restrictions were capped by something far more potent. The local cultural practice of "Chya" (referred to as "Chya-Kyapshe" in Lachung and "Ma-Chya" in Lachen) and colloquially known as "Kalo Puja" in Nepali (translating to black ceremony) was announced as a "last weapon". The Chya is a dreaded public ritual usually undertaken in stealth - when the perpetrator is not known or when the intentions of certain individuals go against the wellbeing of the larger community and their place(s). For the Lachungpas and Lachenpas, mountains and glacial lakes surrounding the two valley regions hold great significance as they are considered to be the abode of their Lhasung(s) (guardian-deities), revered and feared in these high mountain knowledge systems. Chya involves invoking these very local-deities to make a collective curse to punish "unknown" or dangerous perpetrators. This ceremony is performed only after the majority of the Dzumsa members are in consensus. Initiated by paus (sorcerers), this collective cursing is performed with great faith and belief that the perpetrators are punished through an ultimate death for their acts against place and people. The Ma-Chya of Lachen is believed to also be passed on to the perpetrator's future generations. These rituals are thus deeply feared by all in Lachen and Lachung: "We believe in Chya and take it very seriously. People have died unexpectedly in Lachung and Lachen after Chya was performed. Healthy people suddenly contact grave diseases and die, and the cycles of misfortune continue for future generations. The Chya only works on the guilty, this is the greatest feat of its relevance". It is important to note that when a collective decision is made to perform Chya on known or unknown individuals, there is little room to oppose or not engage in this process. This can have repercussions of social exclusion and boycott.

When the power company gained entry in Lachung, Chya-Khyapse was reported to have been performed against those who "sold-out" and/or embezzled funds. In Lachen, where no company was allowed, Ma-Chya was still performed as a deterrent to all Lachenpas from succumbing to the pressure or lure of money. A Lachenpa elderly explained: "The Pipon from Lachen who had some hand in getting the Ministers and company people here was on his way to Gangtok, when he turned ill and died a year later. He was right here with us when Ma-Chya was performed. One could argue that he was suffering from a disease, however, no one had expected him to suddenly die. His death is said to be the effect of Ma-Chya. We hear now that the first expelled Pipon of Lachung who welcomed the company is so scared of the Chya performed on him, that he has been performing one religious ceremony after another to negate the effects of the Chya". It is important to add here that recently, Chya has been banned in Lachung at the request of the Lachung Rinpoche (learned monk) as the Buddhist practice of compassion does not support destruction and ills wished upon another. However, the practice continues in Lachen.

The knowledge and practice of Chya not only deters all hydropower development, it remains a powerful vernacular statecraft against dissent with the Dzumsa. As a Lachungpa youngster states: "Hydropower companies are powerful and supported by the entire government machinery and bureaucracy. There is constant pressure and lobbying by the advocates of power projects. Money plays an important role in these processes. In the face of these challenges, Chya is our only way of preventing this destruction from development from happening". So great is this fear, that numerous attempts by power companies to enter the region have failed. As a Lachenpa reported: "Even after all these events in Lachen, there are continued attempts to woo our Pipons. One of our Pipons was invited to a five-star hotel (Mayfair) in Gangtok and offered India Rupee 9 to 10 crores (equivalent to a little over 1 million in Euro) to work towards public consensus to the dam building agenda. These tactics have not worked".

In fact, government officials who powerfully lobbied on behalf of the power companies elsewhere in Sikkim and showed no hesitation in coercing local communities to agree to these plans, are cautious in doing the same in Lachung and Lachen. Here they try to resort to logical narratives of gains and benefits from hydropower development and yet, when they fail to convince the Lachungpas and Lachenpas, they say, that hydropower development did not happen here, because most of the areas that will be impacted are forest areas-hence individuals will not receive compensation/s. "It is 
simply a clever cost/benefit analysis case. They [Lachung-pas/Lachenpas] know very well that most of the land for hydropower development is in forest areas, meaning less compensation. That's why they resist these plans and are successful in doing so". Nonetheless, the power companies and their advocates keep trying to pursue hydropower development.

The consequences of resisting hydropower development have not been easy for the Lachungpas and Lachenpas. This has resulted in official forms of punishment and coercion, mostly done through job transfers of government employees vocal against the hydropower development plans. A young Lachungpa laments, "I have seen first-hand the politically motivated transfers of our people to faraway places, far away from their families". These developments have only served to strengthen resistance. Giving the example of Tibetans, an old Lachungpa states: "The Tibetans are just refugees for the rest of the world. If our land goes, what will happen to our identity? This is why we have to protect this place for us to stay rooted and come back here no matter where we might occasionally go". This process of exercising territoriality continues. In 2015, a traditional "dress code" was made mandatory in both Lachung and Lachen. Married women in Lachen, and women above 15 years in Lachung have to wear their traditional clothes in their respective regions; while men are required to wear these for all social occasions, especially at funerals.

\section{Discussion}

The findings from this research illustrate how identity constructs and cultural politics play out dynamically in the resistance to hydropower projects by the indigenous Lachungpas and Lachenpas in North-Sikkim. Here, we summarize a couple of key issues for further discussion.

First, resistance to large-scale hydropower development by the Lachung and Lachen communities go far beyond a mere battle against the dreadful material (socio-economic and environmental) impacts that come with mega hydropower development in fragile mountain ecologies. Although these issues were of concern, also because the two communities increasingly rely on a booming tourism industry-where keeping the landscape scenic is vital to people's livelihoods, it was not just concern about possible material losses that led to a collective position of resistance. The Lachungpas and the Lachenpas were deeply concerned about how these new developments would impact upon territoriality - the defense of place (territory), of place-based institutions and the community's unique collective identity as well as their meanings, values and modes of living and knowing. All of these issues are not just central to the ways of being and living for the Lachungpas and the Lachenpas, they are also a powerful means of exercising, asserting and reiterating (collective) identity in the fractured political context of governance in Sikkim. For the Lachungpas and Lachenpas, articulation of their personal and collective identity, of being different, sprouts importantly from their ideas of demarcating territory and constructing (or exercising) territoriality. Territory and territoriality is indeed a key marker of the collective Lachungpa/Lachenpa identity construction. It is their collective identity, interlaced with their historic territorial systems and practices, that has enabled the Lachungpas and Lachenpas to define, project and deploy other kinds of boundaries-moral, cultural, ethnic, economic, political, including their loyalty and solidarities among themselves and against the others. Inwardly and outwardly, territory and identity entwine through the two Dzumsas in their attempt to affect, influence and control people, phenomena, and relationships; thereby demarcating and asserting control over their cultural-political geography. Shared territorial or place-based identity in Lachung and Lachen is the basis around which individual interests are translated into group interests and collective action - which manifests in the projection of a united front against the "others" and "outsiders".

Second, the theoretical analyses discussed in Section 3 explain how an externally imposed agenda of development and the various bearers of these plans and proposals became adversaries which helped both trigger as well as politicize collective identity. The centrality of the Dzumsas in this struggle over territoriality, in making the "benefits of participation and the cost of non-participation as high as possible" [61] (p. 588) cannot be overstated. The role of the Dzumsas in enforcing an agonistic unity is therefore crucial. At the crux of collective identity and associated territorial projections are the Dzumsas, 
which act as binding authorities and steering institutions to engage in locally-particular consciousness, morality and collective action. Collective measures such as threats of social boycott, community expulsion, no-display of political flags, etc., would not be implemented had it not been for the Dzumsa. These measures helped execute a conscious responsibility to keep the Lachungpas/Lachenpas together. Nothing is as sacrosanct as the maintaining of unity amongst the respective Lachungpa and Lachenpas Dzumsa members. As much as the Dzumsas draw their power from the members to acquire and maintain unity, the members draw their power, agency and voice from the Dzumsas, giving rise to a symbiotic dependence on each other. This symbiotic relationship sustains the effectiveness of Dzumsa officials vis-à-vis its members and also provides particular checks-and-balance to each other. In Sikkim, if not for the traditional and customary Dzumsas, the Lachungpa/Lachenpa identity would have been lumped into the broader "Bhutia" identity losing its hallmark distinction. The Dzumsa gives legitimacy to the exclusive collective identity of the Lachungpas and Lachenpas.

Third, as we note, these virtues of cohesion, collective identity and action are not without contradictions-they pose high social, political and emotional risks to those within this community, who for various reasons, might choose to not align with the normative principles of the collective. In addition, territories confining the two Dzumsas and their members within its demarcated areas are socially and politically accessible only to the Dzumsa male members and office bearers. This is not a pluralistic, inclusive institution-rather it operates by restricting intervention or interference from others-making and marking identity and territory are the core functions of the Dzumsa. As we noted, there have been changes in the Dzumsa's structure, functions and customary laws-but these have all been in tune with the interest and wellbeing of the two Dzumsas and its members-rooted in a "local-first" philosophy. This makes the Dzumsa partially exclusionary even within the Lachungpa/Lachenpa community-excluding women, youth, other long-term local residents from its decision-making membership. Even though excluded, they must conform to the institution's norms and dictates. In addition, as seen in the case of the hydropower project development plans, the Dzumsas served to expel its leaders (the Pipons), announce and enact boycotts and the dreaded Chya ceremony against its own members. This is how, as Colloredo-Mansfield analyzed, vernacular statecraft operates and sustains an agonistic unity, which while imperfect, is hugely effective in countering powerful translocal impositions. In continuing to be the sole recognized local institution deciding every socio-economic, environmental and religious affair of the Lachungpas and Lachenpas and their wellbeing-far more intense than the Panchayat System prevalent in the rest of Sikkim, the Dzumsas continue to emerge and evolve as the center of the everyday life-worlds. The degree of involvement is also what reveals the exclusionary side of this all-inclusive institution on grounds of gender, indigeneity, ethnicity, and rationality. It reveals the authoritarian side of the Dzumsa, since loyalty towards the collective and protecting unity and wellbeing of the locality has priority over any other issue.

The fourth and final point we make here is on the plurality of identity. In addition to the divides by gender, age and ethnicity that we discussed above, the Lachungpas and Lachenpas while being a tightly-knit community are nonetheless two groups with particular forms of self-identification. Shared understandings of place and territory, shared cultural values, beliefs and identities allow for a remarkable solidarity between the two groups and yet, when the situation demands, this collective trust and emotion can also turn into expressions of being different. The same can be said for internal dynamics of the Lachungpas and Lachenpas themselves and how historically, loyalty and solidarity is evoked through threat, fear and coercion - when the stakes are high. These dynamics of identity are multiple and complex-like nested matryoshka dolls. Resistance against large dams in Lachen and Lachung illustrates this complex politics of identity and place-based territoriality, whereby indigenous identity is both a culturally rooted and a politically strategic construct. This complexity of identity is unfortunately missing in many analyses of collective resistance against hydropower development in the region. 


\section{Conclusions}

In this paper we have discussed how identity constructs, territoriality and cultural politics by the indigenous Lachungpas and Lachenpas inform resistance to hydropower in North-Sikkim. Resistance is deeply related to the defense of territory, collective identity, and local meanings, values and modes of living and knowing. This defense is strategically organized around the traditional system of self-governance, the Dzumsas. These execute a fundamental responsibility to keep the Lachungpas/Lachenpas together. Dzumsas draw their power from the members to build unity, and members draw their agency and voice from the Dzumsas. The Dzumsa gives legitimacy to the collective identity of the Lachungpas and Lachenpas. Dzumsas mark the Lachungpas and Lachenpas in terms of their distinct history, culture, traditions, their bounded, protected geographical areas including their exclusive tribe status.

Despite local (and official) discourses pretending to "conserve" local indigenous identity, neither this collective identity, nor its triangular relationship with territory and Dzumsas, are fixed and static. Lachungpas and Lachenpas identities are rooted in history, local culture and permanence in the territory, but equally shaped by confrontation with "the outside" (which obviously comes to form part of local identity, culture and indigeneity). From merely being associated with place/location like it did initially, the Lachungpa/Lachenpa identities have today transitioned to encompass and project their territory, distinct culture, ways of living, traditions, traditional institutions including politics at all levels-individual, relational and collective. Therefore, as we have shown, Lachungpas and Lachenpas identities are both "real and rooted" as well as "real and strategic"; often, they are consciously shaped and reshaped, as political actions that serve to defend against/from "outsiders/others" (e.g., hydropower agents) and to protect specific territorial claims and local interests.

The politically-responsive, territorially-exclusive and ethnically-cohesive Dzumsa institutions allow the Lachungpas and Lachenpas to assert enormous political strength. They reshape identity and redefine (ancient) rules and sanctions and whenever necessary (re)create "convenient past", exclusionary relationships or deploy strategic cultural beliefs-evident in a sustained, unanimous "no-hydropower" defense message in the region. Continuously maintained and updated collective identity enables them to engage in fierce, successful collective actions. In times of modernist commensuration through large-scale hydropower development (imposing a common metric to determine "value", "progress", "development", and "efficient hydro-territorial knowledge" [24,88]), the Dzumsas strategically respond with incommensurate cultural-political notions of animated mountains and sacred territory, such as manifested in the Chya ritual practice. This way, the Lachungpas and Lachenpas effectively engage in the battlefield of culture, knowledge and identity, defending and at the same time reshaping their collective identity and territory.

This cohesion, collective identity and collective action and forced normativity, however, make the Dzumsa both an all-inclusive and disciplinary as well as an exclusionary institution, in terms of gender, indigeneity, ethnicity, and rationality. Loyalty towards the collective and protecting unity and wellbeing of the locality has priority over any other issue. This, combined with deeply cultivated notions of territoriality, also informs the Lachungpas/Lachenpas' strict, unanimous no-hydropower stand. "Over my dead body" assertions today by the Lachungpas and Lachenpas, in extremis manifested through the enforcement of Chya, perhaps will keep hydropower development at bay. The irony of the Lachen and Lachung case, one that may be witnessed in many other territories that face modernist encroachment, is that powerful local exclusionary institutions seem to be able to construct forced unity-forms of vernacular statecraft-that effectively counter translocal exclusionary institutions and projects, based on neoliberal agendas of development.

Author Contributions: R.D.D., D.J. and R.B. conceptualized and wrote the paper. R.D.D. framed the overall research project and undertook the field investigation.

Funding: This research was funded by Department of International Development (DFID) through The Netherlands Organisation for Scientific Research (NWO) Grant Number W.O7.68.413. 
Acknowledgments: This paper would not be possible had it not been for the people of Lachung and Lachen for allowing us, random researchers to be a part of their struggle in their guarded spaces and trusting us with their stories. This paper is dedicated to the Lachungpas and Lachenpas of North Sikkim. We are sincerely grateful to all the anonymous reviewers for their constructive comments that went into strengthening our paper. We are also thankful to Jaime Hoogesteger, Wageningen University, for his crucial reading suggestions that have helped shape our paper.

Conflicts of Interest: We declare no conflict of interest. The funders had no role in the design of the study; in the collection, analyses, or interpretation of data; in the writing of the manuscript, and in the decision to publish the results.

\section{References}

1. Joy, K.J.; Mahanta, C.; Das, P.J. Hydropower Development in Northeast India: Conflicts, Issues and Way Forward. 2013. Available online: https:/ / tinyurl.com/yc5fhf5u (accessed on 23 November 2014).

2. Huber, A. Hydropower in the Himalayan Hazardscape: Strategic Ignorance and the Production of Unequal Risk. Water 2019, 11, 414, doi:10.3390/w11030414.

3. Vagholikar, N.; Das, P.J. Damming Northeast India: Juggernaut of Hydropower Projects Threatens Social and Environmental Security of Region, Kalpavriksh, Aaranyak and ActionAid India: Pune/Guwahati/New Delhi. 2010. Available online: https:/ / tinyurl.com/y779olgf (accessed on 10 November 2014).

4. International Rivers. Available online: https://tinyurl.com/yarppgxs (accessed on 5 February 2016).

5. Economic Times. Available online: https:/ / tinyurl.com/yd87b6b3 (accessed on 25 November 2016).

6. Assam Times. Available online: https:/ / www.assamtimes.org/node/18252 (accessed on 15 January 2017).

7. International Rivers. Available online: https://tinyurl.com/y72aywkr (accessed on 22 May 2017).

8. Huber, A.; Joshi, D. Hydropower, Anti-Politics, and the Opening of New Political Spaces in the Eastern Himalayas. World Dev. 2015, 76, 13-25. [CrossRef]

9. Narula, S. The Story of Narmada Bachao Andolan: Human Rights in the Global Economy and the Struggle against the World Bank. New York University Public Law and Legal Theory Working Paper. 2008. Available online: http:/ / lsr.nellco.org/nyu_plltwp/106 (accessed on 6 August 2016).

10. Nepal, P. How Movements Move? Evaluating the role of Ideology and Leadership in Environmental Movement Dynamics in India with Special Reference to the Narmada Bachao Andolan. Hydro Nepal 2009, 4 , 24-29. [CrossRef]

11. Menon, M.; Vagholikar, N. Environmental and Social Impacts of Teesta V Hydro Electric Project, Sikkim: An Investigative Report. 2003. Available online: https:/ / tinyurl.com/ydebeh7na (accessed on 10 November 2014).

12. Huber, A. Contesting Dams and Democracy: State-Society interactions over Hydropower Development in Sikkim, Northeast India. Master's Thesis, Wageningen University, Wageningen, The Netherlands, 2012.

13. Dukpa, R.D.; Joshi, D.; Boelens, R. Hydropower development and the meaning of place. Multiethnic hydropower struggles in Sikkim, India. Geoforum 2018, 89, 60-72. [CrossRef]

14. Thethirdpole. Available online: https://tinyurl.com/y88hh82v (accessed on 3 May 2016).

15. The Indian Express. Available online: https://tinyurl.com/ybcg7m21 (accessed on 3 May 2016).

16. Colloredo-Mansfeld, R. Fighting Like a Community: Andean Civil Society in an Era of Indian Uprising; University of Chicago Press: London, UK, 2009.

17. Klandermans, P.G. Identity Politics and Politicized Identities: Identity Process and the Dynamics of Protest. Political Psychol. 2014, 35, 1-22. [CrossRef]

18. Van Stekelenburg, J.; Klandermans, B. The social psychology of protest. Curr. Sociol. 2013, 61, 886-905. [CrossRef]

19. Klandermans, B.; Van der Toorn, J.; Van Stekelenberg, J. Embeddedness and Identity: How Immigrants Turn Grievances into Action. Am. Sociol. Rev. 2008, 73, 992-1012. [CrossRef]

20. Zomeren, M.V.; Postmes, T.; Spears, R. Towards an integrative Identity Model of Collective Action: A quantitative research synthesis of Three Socio-Psychological Perspective. Psychol. Bull. 2008, 134, 504-535. [CrossRef]

21. Scholtens, J. The elusive quest for access and collective action: North Sri Lankan fishers' thwarted struggles against a foreign trawler fleet. Int. J. Commons 2016, 10, 929-952. [CrossRef] 
22. Melucci, A. Challenging Codes: Collective Action in the Information Age, 1st ed.; Cambridge University Press: New York, NY, USA, 1996.

23. Escobar, A. Territories of Difference: Place, Movements, Life, Reeds, 1st ed.; Duke University Press: Durham, UK; London, UK, 2008.

24. Boelens, R.; Shah, E.; Bruins, B. Contested Knowledges: Large Dams and Mega-Hydraulic Development. Water 2019, 11, 416, doi:10.3390/w11030416.

25. Sawyer, S. Crude Chronicles: Indigenous Politics, Multinational Oil, and Neoliberalism in Ecuador; Duke University Press Books: Durham, UK; London, UK, 2004.

26. Delaney, D. Territory a Short Introduction, 1st ed.; Blackwell Publishing: Hoboken, NJ, USA, 2005.

27. Anguelovski, I.; Alier, J.M. The 'Environmentalism of the Poor' revisited: Territory and place in disconnected glocal struggles. Ecol. Econ. 2014, 102, 167-176. [CrossRef]

28. Duarte-Abadía, B.; Boelens, R. Disputes over territorial boundaries and diverging valuation languages: The Santurban hydrosocial highlands territory in Colombia. Water Int. 2016, 41, 5-36. [CrossRef]

29. Valladares, C.; Boelens, R. Extractivism and the rights of nature: Governmentality, 'convenient communities', and epistemic pacts in Ecuador. Environ. Politics 2017, 26, 1015-1034. [CrossRef]

30. Holsti, K.J. Territoriaalisuus (territoriality). Politiikka 2000, 42, 15-29.

31. Storey, D. Land, territory and identity. In Making Sense of Place: Multidisciplinary Perspectives; Convery, I., Corsane, G., Davis, P., Eds.; Boydell Press: Woodridge, UK, 2012; pp. 11-22.

32. Hoogesteger, J.; Boelens, R.; Baud, M. Territorial pluralism: Water users' multi-scalar struggles against state ordering in Ecuador's highlands. Water Int. 2016, 41, 91-106. [CrossRef]

33. Simon, B.; Klandermans, B. Politicized Collective Identity-A social psychological analysis. Am. Psychol. 2001, 56, 319-331. [CrossRef] [PubMed]

34. Cohen, P.H. Strategy or identity: New theoretical paradigms and contemporary social movements. Soc. Res. 1985, 52, 663-716.

35. Huddy, L. From Social to Political Identity: A Critical Examination of Social Identity Theory. Political Psychol. 2001, 22, 127-156. [CrossRef]

36. Schendel, W.V. Geographies of knowing, geographies of ignorance: Jumping scale in Southeast Asia. Soc. Space 2002, 20, 647-668. [CrossRef]

37. Shneiderman, S. Are the Central Himalayas in Zomia? Some scholarly and political considerations across time and space. J. Glob. Hist. 2010, 5, 289-312. [CrossRef]

38. Michaud, J. Editorial-Zomia and beyond. J. Glob. Hist. 2010, 5, 187-214. [CrossRef]

39. Fisher, J. Introduction. In Himalayan Anthropology: The Indo-Tibetan Interface; Fisher, J., Ed.; Mouton Publishers: The Hague, The Netherland, 1978; pp. 1-3.

40. Sinha, A.C. Sikkim, Institute of Developing Economies: Chiba. 2005. Available online: https://tinyurl.com/ y875gq8t (accessed on 12 July 2015).

41. Government of Sikkim. Gazetteer of Sikkim, Edition 2013; Home Department Government of Sikkim: Gangtok, India, 2013.

42. Government of Sikkim. Human Ecology and Statutory Status of Ethnicity Entities in Sikkim: Report of the Commission for Review of Environmental and Social Sector Policies, Plans and Programmes (CRESP), 1st ed.; Department of Information and Public Relations: Gangtok, India, 2008.

43. Paul, L.M. Sikkimese Ethnologue: Languages of the World, 16th ed.; SIL International: Dallas, TX, USA, 2009.

44. Gohain, S. Mobilising language, imagining region: Use of Bhoti in West Arunachal Pradesh. Indian Sociol. 2012, 46, 337-363. [CrossRef]

45. Bhasin, V. Ecology, Culture and Change: Tribals of Sikkim Himalaya, 1st ed.; Inter-India Publications: New Delhi, India, 1989.

46. Bhasin, V. Social Organisation, Continuity and Change: The Case of the Bhutia of Lachen and Lachung of North Sikkim. J. Biodivers. 2012, 3, 1-43. [CrossRef]

47. Bourdet-Sabatier, S. The Dzumsa of Lachen: An example of a Sikkimese political institution. Bull. Tibetol. 2004, 93-104. Available online: http://www.thlib.org/static/reprints/bot/bot_2004_01_04.pdf (accessed on 28 March 2017).

48. Castells, M. The Power of Identity, 2nd ed.; Wiley-Blackwell: Oxford, UK, 2010.

49. Paasi, A. Region and place: Regional identity in question. Prog. Hum. Geogr. 2003, 27, 475-485. [CrossRef]

50. Wise, J.W. Home: Territory and identity. Cult. Stud. 2000, 14, 295-310. [CrossRef] 
51. Taylor, C. Sources of the Self: The Making of the Modern Identity, 1st ed.; Harvard University Press: Cambridge, MA, USA, 1989.

52. Weinreich, P. The operationalisation of identity theory in racial and ethnic relations. In Theories of Race and Ethnic Relations; Rex, J., Mason, D., Eds.; Cambridge University Press: Cambridge, MA, USA, 1986.

53. Erickson, E.H. The Concept of Identity in Race Relations: Notes and Queries. Daedalus 1966, 95, $145-171$.

54. Massey, D. Geographies of Responsibility. Geografiska Annaler 2004, 86, 5-18. [CrossRef]

55. Weinreich, P.; Saunderson, W. Analysing Identity: Cross-Cultural, Societal and Clinical Contexts, 1st ed.; Routledge: London, UK, 2002.

56. Sedikides, C.; Brewer, M.B. Individual, relational, and collective self: Partners, opponents, or strangers? In Individual Self, Relational Self, and Collective Self; Sedikides, C., Brewer, M.B., Eds.; Psychology: Philadelphia, PA, USA, 2001; pp. 1-4.

57. Opp, K.D. Collective identity, rationality and collective political action. Ration. Soc. 2012, 24, 73-105. [CrossRef]

58. Cakal, H.; Hewstone, M.; Guler, M.; Heath, A. Predicting support for collective action in the conflict between Turks and Kurds: Perceived threats as a mediator of intergroup contact and social identity. Group Process. Intergroup Relat. 2016, 19, 732-752. [CrossRef]

59. Alberici, A.I.; Milesi, P. Online discussion, politicized identity, and collective action. Group Process. Intergroup Relat. 2016, 19, 43-59. [CrossRef]

60. Brubakar, R.; Cooper, F. Beyond “identity". Theory Soc. 2000, 29, 1-47. [CrossRef]

61. Klandermans, B. Mobilization and Participation: Social Psychological Expansions of Resources Mobilization Theory. Am. Sociol. Rev. 1984, 49, 583-600. [CrossRef]

62. Baumeister, R.F.; Leary, M.R. The need to belong: Desire for interpersonal attachments as a fundamental human motivation. Psychol. Bull. 1995, 117, 497-529. [CrossRef] [PubMed]

63. Boelens, R.; Claudin, V. Rooted rights systems in turbulent waters: The dynamics of collective fishing rights in La Albufera, Valencia, Spain. Soc. Nat. Resour. 2015, 28, 1059-1074. [CrossRef]

64. Polletta, F.; Jasper, J.M. Collective identity and social movements. Annu. Rev. Sociol. 2009, $27,283-305$. [CrossRef]

65. Tarrow, S. Power in Movement: Social Movements and Contentious Politics, 3rd ed.; Cambridge University Press: New York, NY, USA, 2011.

66. Zwarteveen, M.Z.; Boelens, R. Defining, researching and struggling for water justice: Some conceptual building blocks for research and action. Water Int. 2014, 39, 143-158. [CrossRef]

67. Mouffe, C. Artistic activism and agonistic spaces. Art Res. 2007, 1, 1-5.

68. Schlosberg, D. Reconceiving environmental justice: Global movements and political theories. Environ. Politics 2004, 13, 517-540. [CrossRef]

69. Loveman, M. High-Risk Collective Action: Defending Human Rights in Chile, Uruguay, and Argentina. Am. J. Sociol. 1998, 104, 477-525. [CrossRef]

70. Bavinck, M. The role of informal fisher village councils (ur panchayat) in Naga-pattinam District and Karaikal, India. In Strengthening Organizations and Collective Action in Fisheries: Towards the Formulation of a Capacity Development Programme; Siar, S., Kalikoski, D., Eds.; FAO: Rome, Italy, 2016; Volume 41, pp. $383-404$.

71. Agrawal, A. Sustainable governance of common-pool resources: Context, methods and politics. Annu. Rev. Anthropol. 2003, 32, 243-263. [CrossRef]

72. Agnew, J. The territorial trap: The geographical assumptions of international relations theory. Rev. Int. Political Econ. 1994, 1, 53-80. [CrossRef]

73. Swyngedouw, E.; Boelens, R. “ ... And Not a Single Injustice Remains”: Hydro-Territorial Colonization and Techno-Political Transformations in Spain. In Water Justice; Boelens, R., Perreault, T., Vos, J., Eds.; Cambridge University Press: Cambridge, MA, USA, 2018; pp. 115-133.

74. Antonsich, M. Rethinking territory. Prog. Hum. Geogr. 2010, 35, 422-425. [CrossRef]

75. Hommes, L.; Boelens, R.; Maat, H. Contested hydro-social territories and disputed water governance: Struggles and competing claims over the Ilisu Dam development in southeastern Turkey. Geoforum 2016, 71, 9-20. [CrossRef]

76. Hommes, L.; Boelens, R. Urbanizing rural waters: Rural-urban water transfers and the reconfiguration of hydrosocial territories in Lima. Political Geogr. 2017, 57, 71-80. [CrossRef] 
77. Hommes, L.; Boelens, R. From natural flow to 'working river': Hydropower development, modernity and socio-territorial transformations in Lima's Rímac watershed. J. Hist. Geogr. 2018, 85-95. [CrossRef]

78. Baletti, B. Ordenamento territorial: Neo-developmentalism and the struggle for territory in the lower Brazilian amazon. J. Peasant Stud. 2012, 39, 573-598. [CrossRef]

79. Moreyra, A. Multiple Territories in Dispute: Water Policies, Participation and Mapauce Indigenous Rights in Patagonia, Argentina. Ph.D. Thesis, Wageningen University, Wageningen, The Netherlands, 2009.

80. Levitas, R.; Pantazis, C.; Fahmy, E.; Gordon, D.; Lloyd, E.; Parsios, D. The Multidimensional Analysis of Social Exclusion. 2007. Available online: http://dera.ioe.ac.uk/6853/1/multidimensional.pdf (accessed on 16 September 2016).

81. Agnew, J.; Oslender, U. Overlapping territorialities. Sovereignty in dispute: Empirical lessons from Latin America. In Spaces of Contention: Spatialities and Social Movements; Nicholls, W., Beaumont, J., Eds.; Ashgate: London, UK, 2013; pp. 121-140.

82. Sack, R.D. Human Territoriality: Its Theories and History, 1st ed.; Cambridge University Press: Cambridge, MA, USA, 1986.

83. Hammersley, M.; Atkinson, P. Ethnography: Principles in Practice, 1st ed.; Tavistock Publication: London, UK; New York, NY, USA, 1984; pp. 1-26.

84. Zaman, S. Native among the Natives: Physisian Antropologists doing hospital ethnography at home. J. Contemp. Ethnogr. 2008, 37, 135-154. [CrossRef]

85. O'Reilly, K. Ethnographic Methods, 1st ed.; Routledge: Abingdon, UK, 2005.

86. Tsuda, T. Ethnicity and the Anthropoligist: Negotiating Identities in the Field. Anthropol. Q. 1998, 17, 107-124. [CrossRef]

87. Ramanathan, K.; Abeygunawardena, P. Hydropower Development in India: A Sector Assessment; Asian Development Bank: Metro Manila, Philippines, 2007; Available online: http:/ /bit.ly/2dioqDY (accessed on 10 November 2014).

88. Hoogendam, P.; Boelens, R. Dams and Damages. Dams and Damages. Conflicting epistemological frameworks and interests concerning "compensation" for the Misicuni project's socio-environmental impacts in Cochabamba, Bolivia. Water 2019, 11, 408, doi:10.3390/w11030408. 